\title{
Komunikasi Ritual pada Budaya Bertani Atoni Pah Meto di Timor-Nusa Tenggara Timur
}

\author{
Yermia Djefri Manafe \\ Universitas Nusa Cendana Kupang, dan kandidat Doktor Ilmu Komunikasi \\ Universitas Padjadjaran Bandung
}

\begin{abstract}
The ritual is one way of communicating. All forms of ritual is communicative. The ritual is always a symbolic behavior in social situations. Because of this ritual is always a way to communicate something. Communication rituals can be understood as meaning the message of a group of people against religious activity and belief system that was followed. The ritual is performed Atoni Pah Meto not independent of trust they hold, in the process always happen meaning of certain symbols that signify the process of ritual communication. This symbol has a meaning known only to those who perform the ritual.
\end{abstract}

Kata Kunci: Ritual, Ritual Communication, Belief System.

\section{Pendahuluan}

Komunikasi ritual merupakan sebuah fungsi komunikasi yang digunakan untuk pemenuhan jati diri manusia sebagai individu, sebagai anggota komunitas sosial, dan sebagai salah satu unsur dari alam semesta. Individu yang melakukan komunikasi ritual menegaskan komitmennya kepada tradisi keluarga, suku, bangsa, ideologi, atau agamanya. Beberapa bentuk komunikasi ritual antara lain, upacara pernikahan, siraman, berdoa (sholat, misa, membaca kitab suci), upacara bendera, momen olah raga, dan sebagainya.

Mulyana (2005:25), mengatakan bahwa komunikasi ritual, biasanya dilakukan oleh komunitas yang sering melakukan upacara-upacara berlainan sepanjang tahun dan sepanjang hidup, yang disebut antropolog sebagai rites of passage, mulai dari upacara kelahiran, sunatan, ulang tahun (menyanyikan Happy Birthday dan pemotongan kue), pertunangan, pernikahan, hingga upacara kematian. Dalam acara-acara tersebut orang-orang mengucapkan kata-kata atau menampilkan perilaku-perilaku tertentu yang bersifat simbolik. Ritus-ritus lain seperti berdo'a, membaca kitab suci, naik haji, upacara wisuda, perayaan lebaran atau Natal, juga adalah komunikasi ritual. Mereka yang berpartisipasi dalam bentuk komunikasi ritual tersebut menegaskan kembali komitmen mereka kepada tradisi keluarga, suku, bangsa, negara, ideologi, atau agama mereka. Komunikasi ritual sering kali bersifat ekspresif, artinya menyatakan perasaan terdalam seseorang, misalnya seorang anggota Paskibraka berlinang air mata ketika mencium bendera pusaka merah putih. Kegiatan komunikasi ritual memungkinkan pesertanya berbagi komitmen emosional dan menjadi perekat bagi keterpaduan mereka. Yang menjadi esensi bukanlah kegiatan ritualnya, akan tetapi adanya perasaan senasib sepenanggungan yang menyertainya, artinya adanya perasaan bahwa kita 
terikat oleh sesuatu yang lebih besar dari diri kita, dan bahwa diri kita diakui dan diterima oleh kelompok kita.

Komunikasi ritual adakalanya bersifat mistik dan seringkali perilaku orang-orang yang ada di dalam komunitas tersebut sulit dimengerti dan dipahami oleh orang-orang yang ada di luar komunitas. Contoh yang dapat dikemukakan adalah upacara-upacara ritual di beberapa suku pedalaman di Indonesia seperti suku Asmat, suku Badui, Dayak, komunitas Atoin Meto dan beberapa suku lainnya yang mata pencahariannya adalah bertani, menangkap ikan di sungai atau di laut, atau berburu binatang.

Komunikasi ritual ini bisa jadi akan tetap ada sepanjang zaman, karena ia merupakan kebutuhan manusia, meskipun bentuknya berubah-ubah demi pemenuhan kebutuhan diri manusia sebagai makhluk individu, anggota komunitas tertentu, makhluk sosial, dan sebagai salah satu bagian dari alam semesta.

Komunitas ritual masyarakat dalam konteks ini adalah masyarakat tani komunitas Atoni Pah Meto. Komunitas Atoni Pah Meto adalah bagian dari etnik Timor di era globalisasi yang pada saat ini masih bertahan dengan kegiatan ritual pada kegiatan pertanian mereka. Petani Atoni Pah Meto, berada dalam suatu masyarakat yang memiliki standar-standar dan regulasi atau aturan umum yang dianut untuk mengatur bagaimana orang-orang atau anggotanya saling berhubungan satu sama lain termasuk kontak dan hubungan dengan kekuatan yang lebih tinggi dan alam lingkungannya. Masyarakat Atoni Pah Meto sebagai masyarakat agraris sebelum menggunakanbenas (parang), fani (kapak), dan kenkanu (linggis) untuk membuka ladang, mereka terikat oleh normanorma suku yang berlaku dalam praktek pengolahan lahan pertanian. Normanorma budaya tersebut merupakan siklus dari ritus-ritus yang dilaksanakan pada setiap satu periode musim tanam.

\section{Ritual dalam Perspektif Komunikasi}

Sebelum lebih jauh mendalami ritual dalam perspektif komunikasi, terlebih dahulu memahami gambaran akan ritual itu sendiri. Menurut Mulyana (2005:25) komunikasi ritual erat kaitannya dengan komunikasi ekspresif adalah komunikasi ritual, yang biasanya dilakukan secara kolektif. Suatu komunitas sering melakukan upacara-upacara berlainan sepanjang tahun dan sepanjang hidup, yang disebut para antropolog sebagai rites of passage, mulai dari upacara kelahiran, sunatan, ulang tahun (nyanyi Happy Birthday dan pemotongan kue), pertunangan (melamar, tukar cincin), siraman, pernikahan (ijab-qabul, sungkem kepada orang-tua, sawer, dan sebagainya), ulang tahun perkawinan, hingga upacara kematian. Selanjutnya menurut Mulyana (2005:25). Dalam acara-acara itu orang mengucapkan kata-kata atau menampilkan perilaku-perilaku tertentu yang bersifat simbolik. Ritus-ritus lain seperti berdoa (salat, sembahyang, misa), membaca kitab suci, naik haji, upacara bendera (termasuk menyanyikan lagu kebangasaan), upacara wisuda, perayaan lebaran (Idul Fitri) atau Natal, juga adalah komunikasi ritual. Mereka yang berpartisipasi dalam bentuk komunikasi ritual tersebut menegaskan kembali komitmen mereka kepada tradisi keluarga, suku, bangsa, negara, ideologi, atau agama mereka.

Menurut Rothenbuhler (1998:28), ritual selalu diidentikkan dengan habit (kebiasaan) atau rutinitas. Rothenbuhler 
selanjutnya menguraikan bahwa, "ritual is the voluntary performance of appropriately patterned behavior to symbolically effect or participate in the serious life". Sementara itu, Couldry (2005:60) memahami ritual sebagai suatu habitual action (aksi turun-temurun), aksi formal dan juga mengandung nilai-nilai transendental. Mencermati pandangan-pandangan tersebut, dipahami bahwa ritual berkaitan dengan pertunjukan secara sukarela yang dilakukan masyarakat secara turun-temurun (berdasarkan kebiasaan) menyangkut perilaku yang terpola. Pertunjukan tersebut bertujuan mensimbolisasi suatu pengaruh dalam kehidupan kemasyarakatan. Lebih jelasnya, Rohtenbuhler (1998:29-33) menguraikan beberapa karakteristik dari ritual itu sendiri sebagai berikut: Ritual sebagai aksi, Pertunjukan (performance), Kesadaran dan Kerelaan, Irasionalitas, Ritual bukanlah sekadar rekreasi, Kolektif, Ekspresi dari Relasi Sosial, Subjunctive dan Not Indicative, Efektifitas simbolsimbol, Condensed Symbols, Ekspresif atau Perilaku Estetik, Customary Behavior, Regularly Recuring Behavior, Komunikasi tanpa informasi, Keramat.

Ritual merupakan salah satu cara dalam berkomunikasi. Semua bentuk ritual adalah komunikatif. Ritual selalu merupakan perilaku simbolik dalam situasi-situasi sosial. Karena itu ritual selalu merupakan suatu cara untuk menyampaikan sesuatu. Menyadari bahwa ritual sebagai salah satu cara dalam berkomunikasi, maka kemudian muncul istilah komunikasi ritual. Istilah komunikasi ritual pertama kalinya dicetuskan oleh James W. Carey (1992:18). Ia menyebutkan bahwa, "In a ritual definition, communication is linked to terms such as "sharing," "participation," "association," "fellowship," and "the possession of a common faith." Hal ini berarti, dalam perspektif ritual, komunikasi berkaitan dengan berbagi, partisipasi, perkumpulan/asosiasi, persahabatan, dan kepemilikan akan keyakinan iman yang sama.

Selanjutnya ditambahkan Carey, dalam pandangan ritual, komunikasi tidak secara langsung diarahkan untuk menyebarluaskan pesan dalam suatu ruang, namun lebih kepada pemeliharaan suatu komunitas dalam suatu waktu. Komunikasi yang dibangun juga bukanlah sebagai tindakan untuk memberikan/ mengimpartasikan informasi melainkan untuk merepresentasi atau menghadirkan kembali kepercayaan-kepercayaan bersama.

Pola komunikasi yang dibangun dalam pandangan ritual adalah sacred ceremony (upacara sakral/suci) dimana setiap orang secara bersama-sama bersekutu dan berkumpul (fellowship and commonality). Senada dengan hal ini, Couldry (2005:15) menambahkan, pola komunikasi dalam perspektif ritual bukanlah si pengirim mengirimkan suatu pesan kepada penerima, namun sebagai upacara suci dimana setiap orang ikut mengambil bagian secara bersama dalam bersekutu dan berkumpul sebagaimana halnya melakukan perjamuan kudus. Dalam pandangan ritual, yang lebih dipentingkan adalah kebersamaan masyarakat dalam melakukan doa, bernyanyi dan seremonialnya.

Menurut Carey

(1992:19), perwujudan atau manifestasi komunikasi dalam pandangan ini bukanlah pada transmisi/pengiriman informasiinformasi intelijen namun diarahkan untuk konstruksi dan memelihara ketertiban, dunia budaya yang penuh makna dimana dapat berperan sebagai 
alat kontrol dalam tindakan/pergaulan antar sesama manusia. Komunikasi ritual diwujudkan dalam bentuk materi seperti tarian, permainan, arsitektur, kisah, dan penuturan. Penggunaan bahasa baik melalui artifisial maupun simbolik (sebagaimana nampak dalam wujud tarian, permainan, kisah, dan tutur lisan) tidak ditujukan untuk kepentingan informasi tetapi untuk konfirmasi; juga tidak untuk mengubah sikap atau pemikiran, tetapi untuk menggambarkan sesuatu yang dianggap penting oleh sebuah komunitas; tidak untuk membentuk fungsi-fungsi tetapi untuk menunjukkan sesuatu yang sedang berlangsung dan mudah pecah (fragile) dalam sebuah proses sosial.

Perspektif ini kemudian memahami komunikasi sebagai suatu proses melalui mana budaya bersama diciptakan, diubah dan diganti. Dalam konteks antropologi, komunikasi berhubungan dengan ritual dan mitologi. Sedangkan dalam konteks sastra dan sejarah, komunikasi merupakan seni (art) dan sastra (literature). Komunikasi ritual pun tidak secara langsung ditujukan untuk menyebarluaskan informasi atau pengaruh tetapi untuk menciptakan, menghadirkan kembali, dan merayakan keyakinan-keyakinan ilusif yang dimiliki bersama.

Komunikasi ritual dalam pemahaman McQuail (2000:54) disebut pula dengan istilah komunikasi ekspresif. Komunikasi dalam model yang demikian lebih menekankan akan kepuasan intrinsic (hakiki) dari pengirim atau penerima ketimbang tujuan-tujuan intrumental lainnya. Komunikasi ritual atau ekspresif bergantung pada emosi dan pengertian bersama.

Menurut McQuail (2000:55), komunikasi dalam pandangan ini merupakan kegiatan yang berhubungan dengan perayaan (celebratory), menikmati (consummatory), dan bersifat menghiasi (decorative). Karena itu untuk mewujudkan terjadinya komunikasi, dibutuhkan beberapa elemen pertunjukan. Komunikasi yang terbangun seperti halnya suatu resepsi yang menyenangkan.

Pesan yang disampaikan dalam komunikasi ritual biasanya tersembunyi (latent), dan membingungkan/bermakna ganda (ambiguous), tergantung pada asosiasi dan simbol-simbol komunikasi yang digunakan bukanlah simbol-simbol yang dipilih oleh partisipan, melainkan sudah disediakan oleh budaya yang bersangkutan. Media dan pesan biasanya agak sulit dipisahkan.

Penggunaan simbol-simbol dalam komunikasi ritual ditujukan untuk mensimbolisasi ide-ide dan nilai-nilai yang berkaitan dengan ramah-tamah, perayaan atau upacara penyembahan dan persekutuan. Simbol-simbol tersebut dibagikan secara luas dan dipahami, walaupun bervariasi dan maknanya samar-samar (McQuail \& Windahl, 1993:55). Komunikasi ritual ini tidak akan pernah selesai/tidak memiliki batas waktu (timeless) dan tidak akan berubah (unchanging). Dalam kehidupan suatu komunitas, komunikasi ritual ini sangat memegang peranan penting, utamanya dalam hubungan sosial kemasyarakatan.

Hammad (2006:3) menyatakan bahwa dalam memahami komunikasi ritual, terdapat ciri-ciri komunikasi ritual sebagai berikut:

1. Komunikasi ritual berhubungan erat dengan kegiatan berbagi, berpartisipasi, berkumpul, bersahabat dari suatu komunitas yang memiliki satu keyakinan sama. 
2. Komunikasi tidak secara langsung ditujukan untuk transmisi pesan, namun untuk memelihara keutuhan komunitas.

3. Komunikasi yang dibangun juga tidak secara langsung untuk menyampaikan atau mengimpartasikan informasi melainkan untuk merepresentasi atau menghadirkan kembali kepercayaankepercayaan bersama masyarakat.

4. Pola komunikasi yang dibangun ibarat upacara sakral/suci dimana setiap orang secara bersama-sama bersekutu dan berkumpul (misalnya melakukan doa bersama, bernyanyi dan kegiatan seremonial lainnya).

5. Penggunaan bahasa baik melalui artifisial (buatan) maupun simbolik (umumnya dalam wujud tarian, permainan, kisah, dan tutur lisan) ditujukan untuk konfirmasi, menggambarkan sesuatu yang dianggap penting oleh sebuah komunitas, dan menunjukkan sesuatu yang sedang berlangsung dan mudah pecah dalam sebuah proses sosial.

6. Seperti halnya dalam upacara ritual, komunikan diusahakan terlibat dalam drama suci itu, dan tidak hanya menjadi pengamat atau penonton.

7. Agar komunikasi ikut larut dalam proses komunikasi maka pemilihan simbol komunikasi hendaknya berakar dari tradisi komunitas itu sendiri, seperti hal-hal yang unik, asli dan baru bagi mereka.

8. Komunikasi ritual atau komunikasi ekspresif bergantung pada emosi atau perasaan dan pengertian bersama warga. Juga lebih menekankan akan kepuasan intrinsic (hakiki) dari pengirim atau penerima.

9. Pesan yang disampaikan dalam komunikasi ritual bersifat tersembunyi (latent), dan membingungkan/ bermakna ganda (ambiguous), tergantung pada asosiasi dan simbolsimbol komunikasi yang digunakan oleh suatu budaya.

10. Antara media dan pesan agak sulit dipisahkan. Media itu sendiri bisa menjadi pesan.

11. Penggunaan simbol-simbol ditujukan untuk mensimbolisasi ide-ide dan nilainilai yang berkaitan dengan keramahtamahan, perayaan atau upacara penyembahan dan persekutuan.

Selanjutnya Couldry (2005:15) menambahkan bahwa dalam komunikasi ritual terdapat tiga terminologi yang saling berkaitan erat. Ketiga hal tersebut adalah communication (komunikasi), communion (komuni/perayaan), dan common (bersama-sama). Kata "komunikasi" sebagaimana ditemukan dalam OED (Oxford English Dictionary), salah satunya, berkaitan erat dengan terminologi komuni (communion) untuk merujuk kegiatan saling bersekutu dan berpartisipasi, berbagi dengan sesama warga, termasuk di dalamnya berbicara dan bercakap-cakap bersama. Komunikasi sebagaimana menggunakan kata penghubung "communion" berarti serangkaian perayaan yang dilakukan untuk menghormati Tuhan. Sebaliknya kata sifat "communicative" berarti orang yang secara terbuka untuk berbicara, bisa bersosialisasi, bebas berkomunikasi, dan banyak omong.

Komunikasi juga berhubungan dengan kata common yakni kepemilikan bersama lebih dari satu orang. OED (1933) mengartikan common: untuk mengkomunikasikan, menyampaikan, membagikan; mengkomunikasikan secara verbal, menjelaskan, mendeklarasikan, menyiarkan, melaporkan; mengambil 
bagian dalam kebersamaan dengan orang lain, berpartisipasi, berbagi, dan berkumpul.

Sejalan dengan pandangan di atas, Dewey (1916) sebagaimana dikutip Carey (1992:22) menekankan, antara kata-kata common, community, dan communication tidak sekedar ikatan verbal. Ditegaskan, orang yang tinggal dalam suatu komunitas memiliki sesuatu yang dipunyai secara bersama; dan komunikasi merupakan cara untuk membuat mereka bisa memiliki hal-hal tersebut secara bersama.

Jadi jelaslah bahwa dalam konteks komunikasi ritual, ketiga elemen (komunikasi, komuni/perayaan, dan kebersamaan) saling kait-mengait. Komunikasi yang dibangun berkaitan erat dengan upacara atau kegiatan komuni/penyembahan suatu komunitas. Sebagaimana halnya suatu komuni, biasanya dilakukan warga suatu komunitas secara bersama-sama.

\section{Fungsi Komunikasi Ritual Pada Sistem Pertanian Atoin Pah Meto}

Ritual yang dilakukan oleh komunitas Atoin Pah Meto selalu dilaksanakan dengan penuh kesungguhan doa dan persembahan berupa korban persembahan seperti ternak terpilih berupa sapi, babi, ayam, dan kambing serta beras, sirih-pinang, minuman keras (sopi) dan lilin. Ritual ini dilakukan pada tempat-tempat persembahan yang dipimpin oleh Tobe (orang yang mempunyai otoritas tinggi dalam urusan tanah), Maveva (tokoh karismatik informal yang mengetahui seluk-beluk kehidupan adat). Ritualritual tersebut ditujukan kepada Uis Neno (Tuhan Maha Tinggi Sang Pencipta)) dan Uis Pah (dewa bumi) yaitu raja lokal sebagai tuan dan arwah leluhur para petani yang disebut $B e^{\prime} i n a^{\prime} i$.

Ritual sering dipahami sebagai sebuah sistem konstruksi kultural atas komunikasi simbolik. Dipraktekan melalui verbal dan non verbal serta tindakan yang diekspresikan dalam berbagai media. Ronal Grimes (1982) mengemukakan model dari ritual berupa, ritualisasi, upacara, liturgi, magis dan perayaan (Fione Bowie, 2000:157).

Kesucian sebagai nilai final atau ultim suatu komunitas bukan hanya dipelihara dengan punishment atau pengucilan dan cap-cap sosial negatif, melainkan juga dengan ritus. Kesatuan yang dibangun atas dasar kepentingan bersama akan yang suci ini melahirkan ritus sosial. Masyarakat menghidupi dirinya dengan bergerak dari dan ke the sacred. Perayaan-perayaan, festival, dan acara-acara budaya dalam masyarakat itu dapat disebut sebagai bentuk-bentuk ritus. Ritus diadakan secara kolektif dan regular agar masyarakat disegarkan kembali akan pengetahuan dan maknamakna kolektif. Ritus menjadi mediasi bagi anggota masyarakat untuk tetap berakar pada the sacred.

Masyarakat tani Atoin Pah Meto meyakini bahwa ritual memiliki fungsi untuk keberkahan dan peningkatan ekonomi yang akan mereka peroleh dari Yang Maha Kuasa setelah mereka melakukan ritual. Komunikasi masyarakat dengan kekuatan yang memberi selamat merupakan sebuah bentuk interaksi yang sarat dengan doa kepada Tuhan atau kepada sesuatu yang mereka percaya memiliki pengaruh terhadap keberadaan mereka secara pribadi maupun terhadap lingkungan di sekitar tempat mereka hidup.

Ritual pada umumnya sarat dengan 
mekanisme yang bersifat simbolik berupa peralatan, mediator dan persembahan. Simbolisasi ini memiliki makna yang hanya diketahui oleh mereka yang menjalankan ritual. Ritual yang dilakukan Atoni Pah Meto tidak terlepas dari kepercayaan yang mereka anut (agama asli/agama suku). Sebagai manusia, komunitas Atoni Pah Meto bukan mahluk horisontal melainkan mahluk yang berakar pada budaya tanah tempat hidupnya. Agama asli mencakup seluruh fenomena tatanan hubungan manusia dengan alam gaib dalam hal mana manusia menyampaikan seruan hati pada kekuasaan mutlak tertinggi yang mengayominya dalam segala ketidaktentuan hidup yang bersifat rohani.

Dalam keagamaan di Indonesia tampaklah aneka warna keyakinan ketuhanan dan paling tua diwakili oleh agama asli atau agama-agama suku. Agama-agama ini selama berabad-abad dipegang teguh oleh rakyat sebagai pedoman hidup dan hingga kini masih tetap terasa pengaruhnya oleh karena mencerminkan unsur-unsur asli kepribadian bangsa kita.

Sistem kepercayaan tradisional di Indonesia memiliki bobot yang cukup untuk disebut sebagai agama dan secara empiris, sistem kepercayaan tradisional mengandung sistem ilmu pengetahuan tentang dunia yang valid (Suwarsono dan Alvin Y.So, 2000:64).

"Istilah agama asli dimaksudkan kerohanian khas yang berasal dari satuan atau suku bangsa dan diperkembangkan di tengahtengah bangsa itu sendiri dan tidak dipengaruhi oleh kerohanian bangsa lain. Kerohanian itu timbul dan tumbuh secara spontan bersama dan berasal dari (suku) bangsa itu sendiri (otokton). Dia tidak bercampur dengan kerohanian agama lain atau (alokthon). Pada hakekatnya terdapat pada masyarakat yang tertutup pergaulannya antar (suku) bangsa. Agama yang mewadahi kerohanian sperti itu disebut Agama Etnis, agama suku, agama preliterate atau agama sederhana" (Subagya, 1981:1-4)

Agama suku terkait dengan tempat dan berkontak dengan agama lain yang mungkin mempertahankan diri sambil berkembang mewujudkan diri lebih lengkap berkat unsur-unsur keagamaan dari luar atau alokhton dan dipribumikan secara selaras atau unsur alokhton diotokhtonkan. Dapat terjadi bahwa agama dari luar yang meskipun agama profetis dan universal tetapi tidak senafas, searah atau sejiwa dengan kerohanian asli, sehingga tidak memungkinkan penyesuaian terbuka dan bebas dengan agama-agama asli. Ia bersifat heretokhton dan atau berbeda dan tidak meluruskan agama asli. Dalam kondisi demikian bangsa tersebut mengalami pengekangan penghayatan agama asli, menderita keretakan jiwa, tertekan, terasa terjajah, tegang sehingga para pelakunya berjiwa mendua dan terasing dari intisari kepribadian dan kerohanian aslinya, dimana ia menerima agama luar secara dangkal. Dalam kondisi demikian agama tidak lagi menjadi nilai vital yang membangun pribadi manusia, tidak pula menghormati Tuhan yang mengaruniakan manusia dengan bekal kerohanian khusus.

Kerohanian agama asli dihayati dalam sikap batin terhadap zat tertinggi dengan nama dan sebutan yang berbedabeda. Sifat hakekatnya mengatasi manusia dan diungkapkan dalam kepercayaan, kesusilaan, adat, nilai, upacara serta perayaan-perayaan yang beraneka ragam.

Manusia menurut kodratnya menyadari bahwa ia terbatas dan lemah, 
sehingga ia mengalami jiwanya terarah kepada alam lain yang mengatasi kelemahan dan keterbatasannya. Alam lain itu alam rohani yang dibayangkan sebagai sesuatu yang utuh, sempurna dan membahagiakan sehingga manusia berusaha mengarahkan kegiatan dan kerinduannya untuk mencapai kebahagian tertinggi tersebut dalam alam rohani dengan cara yang berbeda-beda.

Masyarakat Atoni Pah Meto di Timor merupakan masyarakat agraris bidang pertanian lahan kering dengan sistem bercocok tanam berpindah-pindah dan tebas bakar. Kegiatan petani merupakan suatu perjalanan yang sarat dengan makna dan romantika budaya, hal ini terkait erat dengan agama budaya yang masih melekat erat dalam jiwa mereka. Petani Atoni Pah Meto ini merupakan gambaran dan totalitas kemanusiaanya, hidup dan kehidupannya.

Siklus pertanian Atoni Pah Meto, selalu diawali dengan ritus yang masingmasing memiliki makna tersendiri. Siklus ritus-ritus tersebut merupakan masa-masa kritis yang menentukan periode kehidupan Atoni Pah Meto dalam mengambil keputusan dan atau pilihan keputusan. Memahami, mengajak dan membangun komunitas Atoni Pah Meto harus dipahami dalam sikap dan tingkah laku yang akrab dengan alam lingkungannya. Alam lingkungan Atoni Pah Meto yang bergunung-gunung dengan topografi berlereng-lereng membentuk ketergantungan pada alam.

Ritus-ritus yang dilakukan pada setiap etape bertendensi menjalin dan memelihara hubungan dan komunikasi harmonis antar Atoni Pah Meto dengan kekuatan yang diyakini lebih suci, lebih besar, dan lebih tinggi di luar kemampuan Atoni. Dunia itu adalah dunia Usi Neno
Mnanu (Tuhan Allah) Yang Maha Tinggi yang berada di dunia terang (pah meusine) tak terjangkau (afinit, aneset), api nan tak kunjung padam (apinat, aklahat), roh orang tua yang telah meninggal dunia dan para arwah leluhur (Be'i-na'i), Tuhan Allah yang pendek yaitu usi pah atau Pah Tuaf (tuan tanah). Usi Pah (Usi Neno Pala) dan Be'i-na'i (arwah leluhur) berada di dunia gelap tak kelihatan oleh manusia, yang disebut pah maisokan.

Effendy (2000:55) menggarisbawahi fungsi-fungsi utama dari komunikasi menjadi empat. Pertama, to inform (menginformasikan). Kedua, to educate (mendidik). Ketiga, to entertain (menghibur). Keempat, to influence (mempengaruhi). Sementara itu Harold Lasswell mengemukakan bahwa proses komunikasi dalam suatu komunitas menampilkan 3 fungsi pokok yakni:

1. The surveilance of the environment (fungsi melakukan pengamatan terhadap lingkungan sekitar).

2. The correlation of the parts of society in responding to the environment (fungsi menghubungkan bagian-bagian dari komunitas dalam merespon hal-hal yang terjadi dalam lingkungan sekitar mereka).

3. The transmission of the social heritage from one generation to the next (fungsi mentransmisikan/memindahkan warisan sosial dari suatu generasi kepada generasi selanjutnya).

Bila merujuk pada Rothenbuhler (1998:28) yang menyatakan bahwa ritual selalu diidentikkan dengan habit (kebiasaan) atau rutinitas. Rothenbuhler selanjutnya menguraikan bahwa, "ritual is the voluntary performance of appropriately patterned behavior to symbolically effect or participate in the serious life". Sementara 
itu, Couldry (2005:60) memahami ritual sebagai suatu habitual action (aksi turun-temurun), aksi formal dan juga mengandung nilai-nilai transendental. Mencermati pandangan-pandangan tersebut, dipahami bahwa ritual berkaitan dengan pertunjukan secara sukarela yang dilakukan masyarakat secara turun-temurun (berdasarkan kebiasaan) menyangkut perilaku yang terpola. Pertunjukan tersebut bertujuan mensimbolisasi suatu pengaruh dalam kehidupan kemasyarakatan.

Bila merujuk pada pernyataan di atas, maka dapat disimpulkan bahwa ritual pertanian yang dijalankan masyarakat Atoin Pah Meto adalah bentuk komunikasi tradisional yang mempunyai fungsi sebagai berikut:

1. Ritual sebagai aksi

Ritual merupakan aksi dan bukan hanya sekedar pemikiran atau konsep semata. Dalam kehidupan sehari-hari, mitos adalah salah satu rasionalisasi dari aktifitas ritual. Dengan demikian ritual dipandang sebagai suatu bentuk aksi tidak saja sebagai salah satu cara berpikir. Ritual pun merupakan sesuatu hal dimana orang mempraktekkannya dan tidak saja dipendam dalam benak.

2. Pertunjukan (performance)

Ritual dipertunjukkan sebagai suatu bentuk komunikasi tingkat tinggi yang ditandai dengan keindahan (estetika), dirancang dalam suatu cara yang khusus serta memperagakan sesuatu kepada khalayaknya. Karena menekankan pada unsur estetika, pertunjukan ritual mengandung dua karakteristik. Pertama, ritual tidak pernah diciptakan dalam momentum aksi itu sendiri. Sebaliknya, ritual selalu merupakan aksi yang dida- sarkan pada konsepsi-konsepsi yang ada sebelumnya. Kedua, ritual selalu merupakan pertunjukan untuk orang lain. Pertunjukan tersebut dimaksudkan untuk memperagakan kompetensi komunikasi kepada khalayak.

3. Kesadaran dan Kerelaan

Ritual selalu dilakukan secara sadar dan karenanya bersifat kerelaan. Dalam hal ritual-ritual yang bersifat special event, orang secara sadar untuk terlibat baik sebagai pelaku pertunjukan maupun sebagai penonton. Biasanya untuk terlibat dalam suatu ritual adalah pilihan. Orang dapat memilih untuk terlibat ataupun sebaliknya tidak terlibat.

4. Tidak masuk akal (Irrational)

Seringkali ritual dipandang sebagai tindakan yang irrational (tidak masuk akal) karena dianggap tidak banyak bermanfaat bagi tujuan-tujuan yang spesifik. Parsons dalam Rothenbuhler (1998 : 29) berkesimpulan bahwa pelaksanaan ritual-ritual seringkali diasosiasikan dengan praktek magic. Dalam konteks yang demikian, ritual dipandang tidak masuk akal. Namun, pendapat di atas dibantah oleh Wallace yang menyatakan kalau ternyata tidak semua ritual bersifat irrational dan noninstrumental dalam segala hal. Dalam pandangan Wallace, ritual magic sekalipun dipakai untuk mempertunjukkan fungsi-fungsi sosial yang lain seperti mengurangi keragu-raguan, bagaimana menghasilkan kesepakatan, dan bahkan bisa menginspirasi orang lain untuk bertindak.

5. Ritual bukanlah sekadar rekreasi Berbagai ritual yang dipraktekkan tidaklah sekadar kegiatan rekreasi. 
Walaupun sering terjadi perayaan melalui ritual, namun ritual bukan saja untuk kegiatan hura-hura atau bersenang-senang semata. Sesungguhnya ritual merupakan bagian dari kehidupan yang serius (serious life).

6. Kolektif

Secara menyeluruh, ritual bukanlah sesuatu yang dilakukan secara individual untuk kepentingan individual dalam cara-cara yang murni individualistik. Ritual meskipun dipertunjukkan secara pribadi, tetapi selalu terdapat struktur secara sosial di dalamnya. Misalnya saja: sistem bahasa dan tanda yang digunakan, tradisi, dan moral. Selain itu, ritual juga berorientasi pada suatu kelompok dan umumnya ditampilkan dalam situasi-situasi sosial. Bahkan, ritual tidak saja ditampilkan dalam situasi sosial dan diatur oleh fenomena sosial melainkan ritual juga memiliki makna-makna sosial. Karena itulah Leach mengatakan bahwa ritual selalu merujuk pada relationship (relasi) dan posisi sosial. Ritual pun merupakan salah satu cara dalam mengukur dan menyampaikan maksud-maksud yang berorientasi sosial.

7. Ekspresi dari Relasi Sosial

Ritual meliputi penggunaan modelmodel perilaku yang mengekspresikan relasi sosial. Bentuk-bentuk dari aksi ritual merupakan simbol-simbol dari referen atau penunjuk dalam relasi sosial, perintah-perintah, dan institusi-institusi sosial dimana ritual itu dipertunjukkan.

8. Subjunctive dan Not Indicative

Ritual selalu terjadi dalam modus pengandaian. Hal mana bahwa ritual seringkali berkaitan dengan berbagai kemungkinan seperti bagaimana sebaiknya/seharusnya, dan bukanlah apa menyangkut sesuatu yang sedang terjadi. Sebagaimana Handelman menjelaskan, ritual-ritual boleh saja dipakai sebagai model atau menghadirkan ide berkaitan dengan berbagai peraturan sosial, namun ritual tidak pernah mencerminkan status quo secara struktural.

9. Efektifitas simbol-simbol

Simbol-simbol dalam suatu ritual sangat efektif dan powerful. Kekuatan dari simbol-simbol ritual ini secara jelasnya nampak dalam bentuk ritus. Simbol-simbol ritual selalu berperan dalam semua bentuk ritual. Bahkan, ketika terjadi transformasi sosial yang tidak menampilkan maksud secara eksplisit dari suatu pertunjukan ritual seperti halnya sebuah lagu, tarian, gerak-gerik tubuh, doa, perjamuan, kebiasaan, dan sebagainya. Simbolsimbol tersebut berfungsi sebagai alat komunikasi.

\section{Condensed Symbols}

Simbol-simbol yang singkat merujuk pada karakteristik dari simbolsimbol ritual yang memiliki makna dan aksi ganda. Karenanya, simbolsimbol yang dipersingkat atau kental (condensed symbols) seringkali membingungkan (ambiguous) dan sulit bagi pengamat sosial. Misalnya, simbol dapat ditampilkan dalam cara-cara yang berbeda untuk orangorang yang berbeda; tergantung pada kepekaanmerekaterhadap perbedaanperbedaan valensi. Implikasinya, simbol-simbol mengandung makna lebih dari yang biasanya.

11. Ekspresif atau Perilaku Estetik

Ekspresif adalah salah satu bentuk inti dari ritual dimana mengambil 
posisi sebagai bagian dari apa yang dilakukan dalam ritual serta bagaimana melakukannya. Ritual juga mempunyai komponen estetika yang mendasar. Banyak dari komponenkomponen estetika tersebut sangat menakjubkan.

\section{Customary Behavior}

Ritual merupakan bentuk-bentuk dari perilaku yang bersifat kebiasaan. Ritual mengandung makna pengulangan sebagaimana dilakukan dengan cara yang serupa pada zaman atau era sebelumnya. Artinya, ritual tidaklah dikarang oleh para pelaku. Sebaliknya, ritual merupakan perilaku yang didasarkan menurut kebiasaan atau aturan yang distandarkan. Dengan demikian, perilaku karena kebiasaan ini bersifat imperatif, berkaitan dengan etika, serta perintah sosial.

\section{Regularly Recuring Behavior}

Ritual merupakan perilaku yang dilakukan berulang (repetitive) secara rutin. Banyak ritual yang dilakukan secara terjadwal, dan ditentukan mengikuti suatu siklus waktu. Salahsatu implikasi penting dari ritual yang terjadi secara berkala ini adalah ia tidak diatur dan didikte oleh situasi yang spesifik, melainkan melalui apa yang dipandang benar.

14. Komunikasi tanpa informasi

Sebetulnya ide tentang ritual sebagai suatu komunikasi tanpa informasi menekankan bahwa dalam ritual lebih banyak menampilkan atau mengetengahkan pertunjukan ketimbang informasi. Dalam halhal tertentu, lebih cenderung mengutamakan penerimaan daripada perubahan. Sebagaimana diketahui bahwa ada unsur kerelaan dalam ritual. Kemudian aksi untuk terlibat dalam ritual juga adalah pilihan. Karena itu dalam setiap ritual terkandung sedikit informasi.

\section{Keramat}

Banyak ahli menekankan bahwa ritual adalah aksi yang berkaitan dengan keramat atau sakral. Adapun kriteria dari kesakralan itu adalah menyangkut pola aktifitas atau tindakan dari anggota masyarakat. Contohnya, bagaimana masyarakat menyuguhkan dan memperlakukan obyek-obyek yang dianggap sakral. Tindakan semacam ini mencerminkan suatu tendensi betapa pentingnya suatu benda yang disakralkan tersebut dalam kehidupan mereka.

\section{Daftar Pustaka}

Alavin Y. So, Suwarsono. 2000. Perubahan Sosial dan Pembangunan, LP3S, Jakarta.

Beatty, Andrew. 2001. Variasi Agama di Jawa. Jakarta; Murai Kencana.

Bandem, I Made. 1991. Peranan Seniman dalam Masyarakat,_dalam KONGRES KEBUDAYAAN1991:WarisanBudaya: Penyaringan dan Pemeliharaan. Edisi I. Jakarta: Departemen Pendidikan dan Kebudayaan Direktorat Jenderal Kebudayaan, Direktorat Sejarah dan Nilai Tradisional, Proyek Penelitian Pengkajian dan Pembinaan NilaiNilai Budaya 1992/1993.

Bogdan, Robert C, and Sari Knopp Biklen, 1992, Qualitatif Research for Education: An Introduction to Theory and Methods, Boston: Allyn and CBacon Inc.

Bowie, Fione. 2000. Ritual Theory, Rites of Passage and Ritual Violence. Dalam The Anthropology of Religion.

Carey, James W. 1992. Communication as Culture: Essays on Media and Society. Newyork: Routledge.

Couldry, Nick. 2005. Media Rituals; 
Beyond Functionalism., dalam Media Anthropology. Editor: Eric W. Rothenbuhler dan Mihai Coman. Thousand Oaks: SAGE Publications. Danandjaja, James. 1975. Manfaat Media Tradisional untuk Pembangunan., dalam Kebudayaan dan Pembangunan, SebuahPendekatan terhadap Antropologi Terapan di Indonesia. Penyunting: Nat J. Colleta dan Umar Kayam. Jakarta: Yayasan Obor Indonesia. 1987.

--_---. 1983. "Fungsi Teater Rakyat bagi Kehidupan Masyarakat Indonesia" dalam buku: Seni dalam Masyarakat Indonesia; Bunga Rampai. Editor: Edi Sedyawati \& Sapardi Djoko Damono. Jakarta: PT Gramedia. . 2002. Folklor Indonesia; Ilmu Gosip, Dongeng, dan lain-lain. Jakarta: PT Pustaka Utama Grafiti.

Effendy, Onong Uchjana. 2000. Ilmu, Teori dan Filsafat Komunikasi. Bandung: PT Citra Aditya Bakti.

Geertz, Clifford. 1981. The Religion of Java, London: The Free Pressw of Glencoe.

Koentjaraningrat, 1996, Kebudayaan Mentalitas dan Pembangunan, PT. Gramedia Pustaka Utama, Jakarta.

Kuswarno Engkus. 2008. Etnografi Komunikasi suatu Pengantar dan Contoh Penelitiannya. Widya Padjadjaran. Bandung

Littlejohn and Karen Foss. 1996. Teori Komunikasi. Salemba Humanika. Jakarta

Mardimin, Johanes, 1994. Jangan Tangisi Tradisi-Transformasi Budaya Menuju Masyarakat Indnesia Modern, Penerbit Kanisius, Jogjakarta.

Marzali, Amri. 1997. Kata Pengantar dalam James P. Spradley, Metode Etnografi, terjemahanan Misbah Zulfa Elizabeth, Yogyakarta: Tiara Wacana.

Marzali, Amri. 2005. Antropolgi \& Pembangunan Indonesia. Jakarta: Prenada Media.

Mulyana, Deddy, 2005. Ilmu Komunikasi
Suatu Pengantar. Bandung. Remaja Rosdakarya.

Mulyana, Deddy, 2006. Metode Penelitian Komunikasi. Contoh-Contoh Penelitian Kualitatif Dengan Pendekatan Praktis. Bandung. Rosdakarya

Mulyana, Deddy, 2007. Metode Penelitian Komunikasi. Contoh-Contoh Penelitian Kualitatif Dengan Pendekatan Praktis. Bandung. Rosdakarya

Mulyana, Deddy, 1995. Twenty Five Indonesians in Melbourne (Desertasi dalam rangka memperoleh Ph.D di Universitas Monash, Australia).

McQuail, Denis. 2000. McQuail's Mass Communication Theory. London, Thousand Oaks, New Delhi: SAGE Publications.

Purba, Jonny, dkk. 2002. Pemberdayaan Masyarakat Adat dalam Pengelolaan Lingkungan. Prosiding Lokakarya. Jakarta: Aliansi Masyarakat Adat Nusantara.

Rakhmat, Jalaludin, 1997, Metode Penelitian Komunikasi, Bandung Remaja Rosdakarya.

Ritzer, George. 1992. Sosiologi Ilmu Pengetahuan Berparadigma Ganda (penyadur Alimandan), Rajawali Pers, Jakarta.

Rothenbuhler, Eric W. 1998. Ritual Communication: From Everyday Conversation to Mediated Ceremony. Thousand Oaks. SAGE Publications.

Rothenbuhler, Eric W. dan Mihai Coman. 2005. The Promise Of Media Anthropology, dalam Media Anthropology. Editor. Eric W. Rothenbuhler dan Mihai Coman. Thousand Oaks. SAGE Publications.

Spradley, James. P. 2006. Metode Etnografi. Pengantar: Amri Marzali. Yogyakarta: Tiara Wacana Yogya.

Soedjatmoko, 2001. Kebudayaan Sosial, Melibas, Jakarta.

Soekanto, Sastrosapono, dan Taneko 1981. Majalah Peninjau 